\title{
The Importance of Organizational Communication in Improving Employee Performance: A Case Study of the Regional Revenue Management Agency of the City of Bandung
}

\author{
Farida Yuliaty \\ Universitas Sangga Buana, Bandung, Indonesia \\ Email: farida.yuliaty@usbypkp.ac.id
}

\begin{abstract}
This study aims to examine the effect of organizational communication on employee performance at the Bandung Regional Revenue Management Agency, both simultaneously and partially. This study uses explanatory surveys to analyze the influence between variables, both partially and simultaneously. Data collection was carried out by distributing questionnaires to 60 respondents who were sampled in the study. Data analysis and hypothesis testing in this study were carried out using path analysis. This research proves that organizational communication simultaneously and partially influences the performance of employees at the Bandung Regional Revenue Management Agency.
\end{abstract}

Keywords: Downward Communication, Upward Communication, Horizontal Communication, Performance.

\section{A. INTRODUCTION}

Human resources are one of the important things in an organization (Pereira \& Anderson, 2012). Whatever the form and purpose, an organization is founded based on a vision for the common good, and in carrying out its mission managed by all. Labour or employees is the most valuable thing in the organization. Without labour or employees who have high intensity, it is impossible for organizational goals to be achieved well (Pasban \& Nojedeh, 2016).

The organization is carried out in a system consisting of activities carried out regularly and repeatedly by a group of people in order to achieve goals. To achieve the goals of an organization must be supported by quality resources both material, capital and human intangibles. The available resources if not managed properly will not obtain the goals that have been made, so a step from a leader is very important because it can use its authority and leadership to achieve a common goal (Jabbour \& Santos, 2008).

The organization is a system consisting of a group of people who work together through the division of work and functions to achieve the goals set. Inside there is a structure that shows the hierarchical relationship between superiors and subordinates, subordinates and superiors, and fellow subordinates (Alvesson, 2013). Relationship between superiors and subordinates in the organization can be seen for example when superiors convey information to subordinates related to policies and regulations that apply in the organization and organizational goals. Bosses deliver 
instructions/orders to subordinates according to the division of roles and tasks of each member of the organization. The subordinates submit reports to superiors when the process of carrying out the task takes place or afterwards. Interactions that occur between members of the organization both between superiors and subordinates, subordinates with superiors, as well as fellow subordinates or fellow superiors are created through a communication process (Men \& Stacks, 2014).

Based on the facts above, communication is a binding thing for organizational unity. Communication helps complete the tasks of organizational members in achieving goals (Reed, 2010). Communication coordinates the activities or activities of the organization and plays a role in almost all relevant organizational actions (Cooren, 2011). Robbins \& Jones (1982), revealed that modern organizations are a complex structure of a variety of activities with only communication, these activities can be arranged and united to achieve a goal.

Communication is the process of exchanging messages both verbal and nonverbal between the sender of the message with the recipient of the message to change behaviour. The sender of the message can be individuals, groups or organizations. Similarly, recipients of messages can be individuals, groups or organizations. The communication process is a reciprocal process because there is a process of mutual influence between the sender of the message and the recipient of the message so that changes in behaviour occur (Cho, et al., 2013).

Communication is a source of organizational life. The life and death of an organization depend on the communication process that takes place in it. Bernard in Thoha (1998), said that "every complete organization, communication will occupy a major place because the composition, breadth and scope of the organization as a whole are determined by communication techniques". Based on the opinion above, it is clear that communication plays a role in an organization.

According to Goldhaber, organizational communications is the process of creating and exchanging messages within a network of interdependent relationships to cope with environmental uncertainly (Muhammad, 2005). Communication that takes place among members of an organization has an influence on the performance of its members (Giri \& Kumar, 2010; Hendriani \& Hariyandi, 2014; Irawan \& Venus, 2016; Anshari \& Amin, 2017). Good communication can increase mutual understanding, and cooperation between members of the organization so that it produces good performance (Rajhans, 2012; Indrasari et al., 2019). A smooth communication process will avoid differences in perception so that organizational goals will be achieved. But on the contrary, the process of communication that does not smoothly give adverse effects to the organization in terms of effectiveness and work efficiency. Misinformation due to lack of understanding in understanding the instructions given resulted in subordinates mistakenly carrying out orders from superiors so that the time required to complete the work exceeds the estimated time that has been determined, in other words, the performance of the prison employee is less than optimal. 
In accordance with Bandung Mayor Regulation Number 1405 of 2016 concerning the Work Procedures of the Bandung Regional Revenue Management Agency, the Bandung Regional Revenue Management Agency has the task of assisting the Mayor of Bandung in carrying out supporting functions of government affairs which are the regional authority in the field of tax, retribution and regional income management. Based on the results of the identification of problems that occur in the Bandung Regional Revenue Management Agency, researchers found that employee performance was not optimal as seen from aspects of performance such as the quantity of work not in accordance with the targets set, the quality of work was not in line with expectations, and the completion of work which is not timely.

Based on these performance aspects, it is suspected that there are factors that cause communication in the organization not yet optimal. This is evident in the case of misinformation received by subordinates when receiving orders from superiors to carry out a work task. The unclear information or different understanding between the recipient of the order and the giver of the order often results in the execution of tasks that do not approach the objectives or do not meet the allotted time. Based on the description above, this study aims to examine the effect of organizational communication on employee performance at the Bandung Regional Revenue Management Agency, both simultaneously and partially.

\section{B. LITERATURE REVIEW, THEORETICAL FRAMEWORK, AND HYPOTHESES}

This research focuses on the analysis of organizational communication theory and employee performance accompanied by several supporting theories that have a relationship or correlation with the research conducted.

According to the origin of the word communication or communication in English comes from the Latin communis which means "same" or shared, communico, communicatio, or communicare which means "to make common". The term communis is the term most often referred to as the origin of the word communication. So the communicator or sender of the message trying to find common ground or togetherness with the communicant (receiver of the message).

Communication is a source of organizational life. Organizational life depends on the communication process that takes place in it. Bernard in Thoha (1998), said that every complete organization, communication will occupy a major place, because the composition, breadth and scope of the organization as a whole is determined by communication techniques. Organizations need the information to live because without information the organization stagnates. Through the communication process, information can be obtained. That information is processed, transmitted and exchanged between members of the organization to achieve a goal.

Organizational communication is the sending and receiving of messages within the organization in formal and informal groups in the organization. So, organizational communication can be interpreted as communication that occurs 
between people who are inside the organization itself, also between people who are inside the organization with the outside public, with a view to achieving a goal.

According to Goldhaber in Muhammad (2005), organizational communications is the process of creating and exchanging messages within a network of interdependent relationships to cope with environmental uncertainly. There are seven important points of the definition, namely process, message, network, interdependence, relationship, environment and uncertainty. Communication is said to be a process because it creates and exchanges messages continuously. Adler \& Rodman (2000), dividing the flow of communication within organizations includes vertical communication consisting of downward communication, upward communication, and horizontal communication.

Downward communication is communication that takes place when people at a higher level send a message to a lower level or in other words the message flows from the boss to subordinates. This downward flow of communication includes: giving or delivering work instructions, an explanation from the leadership about why a task needs to be carried out (job rationale), delivering information about applicable regulations (procedures and practices), and providing motivation to employees to work better. These four things are conveyed by superiors to subordinates.

Through this communication below, subordinates can find out what to do and how to do work according to the instructions (job instructions) given by superiors. Subordinates can also find out how their work relates to other tasks and positions in the organization and why they do their work so that it can help the organization in achieving its goals. Downward communication also includes the delivery of information from superiors to subordinates regarding organizational practices, organizational regulations, habits, and other data that is not related to instruction and rational. Superiors communicate with subordinates by explaining how well subordinates have worked and by how subordinates can improve their performance. Thus, subordinates feel motivated to produce a good performance.

Upward communication is communication that takes place when people at the lower level of the hierarchy send messages to a higher level or in other words messages flow from subordinates to superiors. This upward flow of communication includes submission of information about work or tasks that have been carried out, submission of information about work problems or tasks that cannot be completed by subordinates, submitting suggestions for improvement from subordinates, and submitting complaints from subordinates about themselves or his work Those are the things that are expected by the leadership to be conveyed by subordinates to their superiors through upward communication.

Through communication to the top, superiors can find out what their subordinates are doing, their work, the results they have achieved and their progress in carrying out their duties. If in carrying out their duties, they face problems, subordinates need to submit them to superiors so that they can be assisted so that the implementation of tasks runs smoothly. Subordinates also need to provide 
suggestions or ideas to superiors for improving their respective work units and for the organization as a whole. Likewise, the thoughts and feelings of subordinates regarding work, colleagues and organization need to be conveyed to superiors.

The next flow of communication is horizontal communication. This communication takes place between employees or sections that have an equal position or in other words the exchange of messages takes place between people of the same level of authority in the organization. The function of this horizontal communication flow is to coordinate tasks, solve problems, share information and foster relationships through joint activities. The first horizontal communication function is the coordination of tasks. Section heads in an organization sometimes need to hold meetings or meetings to discuss how each section contributes to achieving organizational goals. The emergence of problems in the implementation of tasks in the organization is often encountered and must be immediately addressed. Therefore, people who are at the same level trying to get involved in solving the problem at hand. They also share information with each other in search of better ideas. It is undeniable that most of the work time of members of the organization interact with each other so they get the support of interpersonal relationships from friends. This will strengthen the relationship between them and help cohesiveness in group work. Thus the form and function of horizontal communication in an organization.

The results of research O'Reilly \& Robert in Muhammad (2005), Pettit (1997), and Manis, et al. (1978) strongly support that there is a relationship between the quality and quantity of communication with performance. This was confirmed by Robbins (2001), who revealed that organizational communication can maintain employee motivation by giving employees an explanation of what needs to be done, how well they are doing it and what employees can do to improve their performance if it is below standard.

Performance is an achievement or work results in activities that have been planned and implemented by a person or group of people to achieve the goals set and expected results within an organization within a certain period of time. Performance appraisal has an important role in the sustainability of the organization in achieving its objectives, it is needed dimensions and indicators in measuring performance.

Bernardin \& Russel in Darmawan (2013), stated that there are six dimensions used to measure employee performance individually, namely quality, quantity, timeliness, cost-effectiveness, need for supervision, and interpersonal impact. So based on Bernardin and Russel's opinion, performance tends to be seen as a result of a work process whose measurements are carried out within a certain time period by looking at factors of quality, quantity, timeliness, cost-effectiveness, need for supervision, and interpersonal impact.

Based on the description above, it can be stated that organizational communication influences employee performance (Giri \& Kumar, 2010; Hendriani \& Hariyandi, 2014; Irawan \& Venus, 2016; Ansari \& Amin, 2017; Rajhans, 2012; 
Indrasari et al., 2019). Both are important elements in public administration and human resource management. Based on the description above, the research paradigm is arranged in the following framework of thought:

\begin{tabular}{|c|c|c|}
\hline $\begin{array}{c}\text { Organizational } \\
\text { Communication }(\mathbf{X}) \\
\text { (Adler \& Rodman, 2000) }\end{array}$ & Giri \& Kumar, & $\begin{array}{c}\text { Employee Performance (Y) } \\
\text { (Bernardin \& Russel in } \\
\text { Darmawan, 2013) }\end{array}$ \\
\hline $\begin{array}{l}\text { 1. Downward } \\
\text { Communication } \\
\text { 2. Updard Communication } \\
\text { 3. Horizontal } \\
\text { Communication }\end{array}$ & 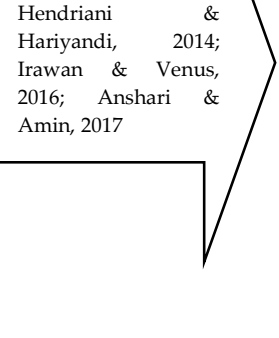 & $\begin{array}{l}\text { 1. Quality } \\
\text { 2. Quantity } \\
\text { 3. Timeliness } \\
\text { 4. Cost Effectiveness } \\
\text { 5. Need for Supervision } \\
\text { 6. Interpersonal Impact }\end{array}$ \\
\hline
\end{tabular}

Figure 1 Paradigm Influence of Organizational Communication on Employee Performance

Based on the literature review above, the hypotheses in this study are as follows:

$\mathrm{H}_{1}$ : Simultaneous organizational communication has an impact on employee performance at the Bandung City Revenue Management Agency.

$\mathrm{H}_{2}$ : Organizational communication consisting of downward communication, upward communication and horizontal communication partially affect the performance of employees at the Bandung Regional Revenue Management Agency.

\section{METHOD}

This research was conducted at the Regional Revenue Management Agency of the City of Bandung, West Java Province, Indonesia. The research method used in this study is the explanatory survey method (De Leeuw, 2008; Groves et al., 2011). The selection of this method is based on the consideration that this method not only explains or illustrates empirical facts in the field but will also explain the analysis of influence (Punch, 2003).

Operationally this research includes two variables, consisting of independent variables namely Organizational Communication $(X)$, while the dependent variable is Employee Performance (Y). The sample in this study were employees of the Bandung Regional Revenue Management Agency totalling 60 people drawn by the census (total sampling). Data collection techniques used questionnaires. Data analysis techniques in this study use path analysis to see the effect of organizational communication on employee performance, both partially and simultaneously. 


\section{RESULTD AND DISCUSSION}

Simultaneous test results obtained influence of organizational communication $(\mathrm{X})$ on employee performance $(\mathrm{Y})$ of 0.624 which is the square of the multiple correlation coefficient $(R=0.790)$, while the magnitude of the influence of other variables not examined in this study amounted to 0.376 , for For more details, can be seen in Figure 2 below:

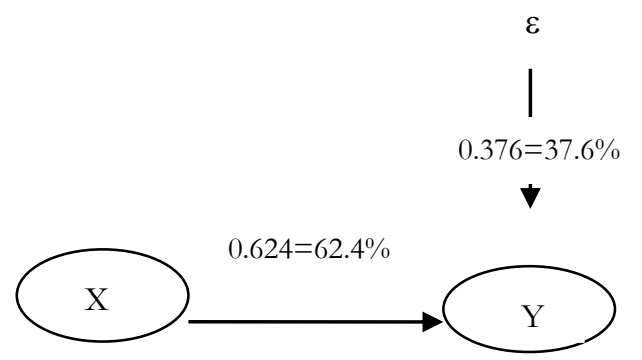

\section{Figure 2 The Influence of Organizational Communication $(X)$ on Employee Performance (Y)}

Based on the results of the analysis of the coefficient of determination/test of influence contribution, it shows that organizational communication variables influence employee performance is 0.624 or $62.4 \%$. Organizational communication consists of three dimensions, namely: downward communication, upward communication, and horizontal communication that has a strong influence on employee performance consisting of six dimensions, namely: Quality, Quantity, Timeliness, Cost Effectiveness, Need for Supervision and Interpersonal Impact. Organizational communication consisting of downward, upward communication and horizontal communication dimensions has a $62.4 \%$ effect on employee performance consisting of the dimensions of Quality, Quantity, Timeliness, Cost Effectiveness, Need for Supervision and Interpersonal Impact while the rest is equal to $37.6 \%$ is influenced by other variables not examined in this research.

The test results partially obtained the value of the path coefficient $X 1$ to $Y$ is 0.162 , the influence of $\mathrm{X} 2$ to $\mathrm{Y}$ is 0.215 , and the influence of $\mathrm{X} 3$ to $\mathrm{Y}$ is 0.246 . While the magnitude of the influence of other variables not examined was 0.378 . For more details, a large influence can be seen in the picture as follows:

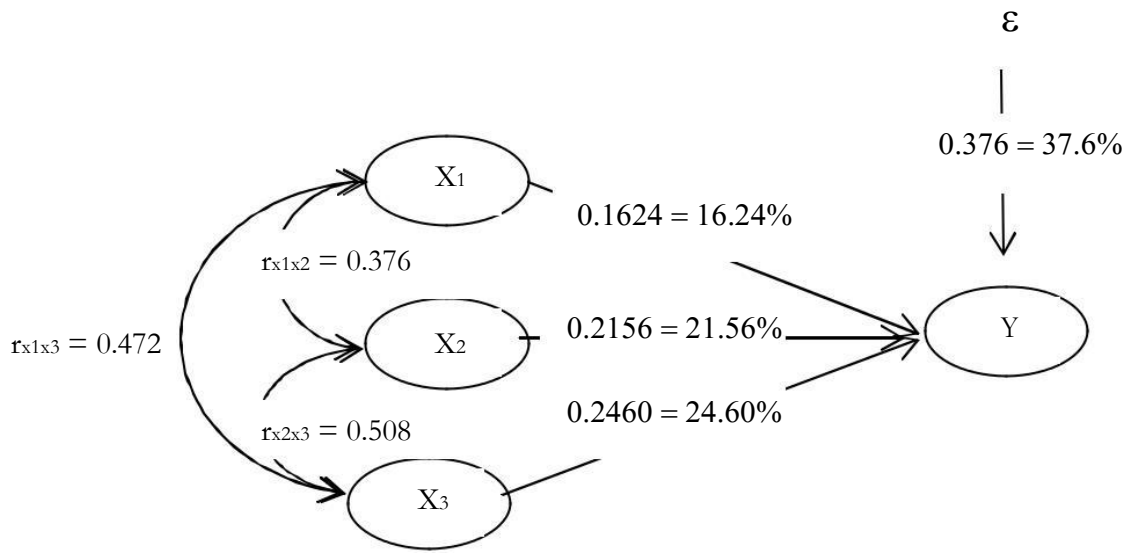

Figure 3 Magnitude of Effect of Dimensions X1, X2 and X3 to $Y$ 
The results of data processing indicate that downward communication has an effect on employee performance by 0.1628 or $16.28 \%$. The communication characteristics below consist of indicators for the delivery or delivery of work instructions, an explanation from the leadership about why a task needs to be carried out, delivery of information regarding applicable regulations and motivation giving while employee performance is represented by the dimensions of Quality, Quantity, Timeliness, Cost Effectiveness, Need for Supervision and Interpersonal Impact.

The dimensions of communication upward affect employee performance is 0.215 or $21.5 \%$. The communication characteristics consist of indicators of task implementation reports, delivery of work problems, submission of suggestions for improvement as well as personal and work complaints, while employee performance is represented by the dimensions of Quality, Quantity, Timeliness, Cost Effectiveness, Need for Supervision and Interpersonal Impact.

The dimensions of horizontal communication affect the performance of employees is equal to 0.246 or $24.6 \%$. The characteristics of horizontal communication consist of indicators of task coordination, problem-solving, information sharing, and fostering cooperative relationships, while employee performance is represented by the dimensions of Quality, Quantity, Timeliness, Cost Effectiveness, Need for Supervision and Interpersonal Impact.

The dimension of communication to the top has the greatest influence on employee performance followed by the dimension of horizontal communication to employee performance, while the smallest influence on employee performance is the communication dimension downward.

The results of this study reinforce previous findings that organizational communication influences employee performance (Giri \& Kumar, 2010; Hendriani \& Hariyandi, 2014; Irawan \& Venus, 2016; Anshari \& Amin, 2017; Rajhans, 2012; Indrasari et al., 2019). Both are important elements in public administration and human resource management.

\section{E. CONCLUSION}

Based on the results of research and discussion, several conclusions can be drawn. First, simultaneously, organizational communication variables affect employee performance. This implies that operationally organizational communication is very important and very supportive of improving employee performance. Researchers also found that employee performance variables were not only influenced by organizational communication variables, but there were other variables that also influenced employee performance that needed to be further investigated to develop the concept of organizational communication theory more broadly in accordance with the development of organizational life. Second, partially, organizational communication variables consisting of the dimensions of downward communication, upward communication and horizontal communication affect the performance. The dimension of communication to the top has the greatest influence 
on employee performance followed by the dimension of horizontal communication to employee performance, while the smallest influence on employee performance is the communication dimension downward.

\section{REFERENCES}

1. Adler, R. B., \& Rodman, G. (2000). Understanding Human Communication. Oxford: Oxford University Press.

2. Alvesson, M. (2013). Communication, power and organization (Vol. 72). Walter de Gruyter.

3. Anshari, H., \& Amin, M. J. (2017). Pengaruh Komunikasi Organisasi Dan Budaya Organisasi Terhadap Kinerja Pegawai Bagian Sosial Sekretariat Daerah Kabupaten Kutai Timur. Jurnal Administrative Reform (JAR), 2(3), 397-409.

4. Bandung Mayor Regulation Number 1405 of 2016 concerning the Work Procedures of the Bandung Regional Revenue Management Agency

5. Cho, J., Park, D. J., \& Ordonez, Z. (2013). Communication-oriented personorganization fit as a key factor of job-seeking behaviors: Millennials' social media use and attitudes toward organizational social media policies. Cyberpsychology, Behavior, and Social Networking, 16(11), 794-799.

6. Cooren, F., Kuhn, T., Cornelissen, J. P., \& Clark, T. (2011). Communication, organizing and organization: An overview and introduction to the special issue. Organization studies, 32(9), 1149-1170.

7. Darmawan, D. (2013). Prinsip-Prinsip Perilaku Organisasi.Surabaya: Pena Semesta.

8. De Leeuw, E. D., Hox, J. J., \& Dillman, D. A. (2008). International handbook of survey methodology. Taylor \& Francis Group/Lawrence Erlbaum Associates.

9. Giri, V. N., \& Kumar, B. P. (2010). Assessing the impact of organizational communication on job satisfaction and job performance. Psychological Studies, 55(2), 137-143.

10. Groves, R. M., Fowler Jr, F. J., Couper, M. P., Lepkowski, J. M., Singer, E., \& Tourangeau, R. (2011). Survey Methodology (Vol. 561). John Wiley \& Sons.

11. Hendriani, S., \& Hariyandi, F. (2014). Pengaruh Motivasi dan Komunikasi terhadap Kinerja Pegawai di Lingkungan Sekretariat Daerah Provinsi Riau. Jurnal Aplikasi Bisnis, 4(2), 124-156.

12. Indrasari, M., Syamsudin, N., Purnomo, R. B., \& Yunus, E. (2019). Compensation, Organizational Communication, and Career Path as Determinants of Employee Performance Improvement. Humanities $\mathcal{E}$ Social Sciences Reviews, 7(4), 956-961.

13. Irawan, D., \& Venus, A. (2016). Pengaruh Iklim Komunikasi Organisasi Terhadap Kinerja Pegawai Kantor Keluarga Berencana Jakarta Barat. Jurnal Kajian Komunikasi, 4(2), 122-132.

14. Jabbour, C. J. C., \& Santos, F. C. A. (2008). The central role of human resource management in the search for sustainable organizations. The International Journal of Human Resource Management, 19(12), 2133-2154. 
15. Manis, M., Fichman, M., \& Platt, M. B. (1978). Cognitive integration and referential communication: Effects of information quality and quantity in message decoding. Organizational Behavior and Human Performance, 22(3), 417-430.

16. Men, L. R., \& Stacks, D. (2014). The effects of authentic leadership on strategic internal communication and employee-organization relationships. Journal of Public Relations Research, 26(4), 301-324.

17. Muhammad, A. (2005). Komunikasi Organisasi. Jakarta: Bumi Aksara.

18. Pasban, M., \& Nojedeh, S. H. (2016). A Review of the Role of Human Capital in the Organization. Procedia-social and behavioral sciences, 230, 249-253.

19. Pereira, V., \& Anderson, V. (2012). A longitudinal examination of HRM in a human resources offshoring (HRO) organization operating from India. Journal of World Business, 47(2), 223-231.

20. Pettit Jr, J. D., Goris, J. R., \& Vaught, B. C. (1997). An examination of organizational communication as a moderator of the relationship between job performance and job satisfaction. The Journal of Business Communication (1973), 34(1), 81-98.

21. Punch, K. F. (2003). Survey Research: The Basics. London: Sage Publications.

22. Rajhans, K. (2012). Effective organizational communication: A key to employee motivation and performance. Interscience Management Review, 2(2), 81-85.

23. Reed, M. (2010). Is communication constitutive of organization?. Management Communication Quarterly, 24(1), 151-157.

24. Robbins, S. P. (2001). Perilaku Organisasi. Jakarta: Prinhalindo.

25. Robbin, J. G., \& Jones, B. S. (1982). Komunikasi: yang Efektif. Pemimpin, Pejabat dan Usahawan (Effective Communication Todays Manager). Jakarta: Tulus Jaya.

26. Thoha, M. (1998). Perilaku Organisasi, Konsep Dasar dan Aplikasinya. Jakarta: Raja Grafindo Persada 